\title{
The Novel as a Picture of Nature
}

"He is the best novelist who describes men with perfect fidelity," the Harper's reviewer had written. Description, as I noted in chapter 6, has a different textual force from narration. Its subject is static, and to conceive of the novel as descriptive is to remove the emphasis from story and the dynamic, emotional, immediate involvement that story creates in readers. To equate the achievement of something static with the better novel meant that storytelling, though remaining the defining formal characteristic of the novel, was less and less admired as its reason for being. Novels that were purely story, no matter how well done, were not seen as striving for the highest reaches of novelistic art, and novels that were superior were judged so on the basis of something other than their stories. This distinction remains in force today, just as reading for story rather than meaning is still considered a less admirable kind of activity. In effect, the critic is looking for novels that are moral statements, for novelists who are moralists. Evidently pure story is thought to be childish, frivolous, and-above all-lacking in moral weight. But defining the better novel in such a way as to ignore or downplay its fundamental formal feature does not merely modify the form, it undercuts it; and the critics' effort (along with the novelists who also wanted to make the novel a weighty moral achievement) was in essence a co-optation of the popular form for less popular uses.

The language in which reviewers wrote about and praised the novel as a form representing static reality was, perforce, taken 
from a nonliterary artistic form. It was the language of painting. There is nothing new, or specific to the novel, in the alliance of painting (or, more generally, pictures) with literature. But this alliance has different results when its literary subject is the plotgenerated novel as opposed, say, to lyric poetry, because it enhances the spatial at the expense of the dynamic. One of the impulses behind this behavior, an impulse common to intellectual discourse in many fields, is the emphasizing of sight over other senses. For literature generally the practice drops out the appeal to sound and severs the tie between writing and speech. Among many ramifications where the novel is concerned, the practice erases the temporal field, overwrites the novel as a form that unfolds itself inevitably in time, and permits the reviewer to reconstitute it as a complete, framed object that he and the reader can step back from and examine in a spatial totality. Insofar as this routine makes the work seem more representational than it would appear if a temporal, voice-centered model were used, it can only be because reality itself is thought of as something complete and fixed from which the observer can be abstracted. The stance implied here is opposed to that implied in formal notions of the novel as plot, because it is the essence of plot, and the reader response connected with it, interest, to be engaged, caught up-not to be standing back, not to be an observer. To view the novel as a picture implies ideas about reality and how to encompass it that are basically different from those implied when one views the novel as a plot.

Besides downplaying plot and the emotional responses it engendered, talking about novels as though they were pictures obscured or mystified such other elements of fiction as style and characterization, producing criticism that praised a novel for representational fidelity without providing any clue to how that fidelity had been achieved. To some degree this was a useful strategy in that it enabled reviewers to avoid grappling with the basic question of how nonlinguistic experience or existence (putting aside for the moment the matter of whether anything can be experienced without language) can fairly be represented through it. Language in a play was clearly representational, in that it represented characters talking. Dialogue in a novel was mimetic in the same way. But for all other aspects of the novel language was representational only by virtue of a set of mediating conven- 
tions that the American Victorian left unexamined. The use of a painterly rhetoric for discussing novels allowed reviewers to leap over a gap that, as the history of criticism in the twentieth century shows, could only threaten the status of the novel as a vehicle for representation. Of course, if the reviewers had not wanted to make the novel a vehicle for representing the human condition, the gap would not have been there to leap over. The problem is a direct result of the paradigm. The paradigm in turn is a response to two differently oriented reviewer desires: first, to separate novels from their powerful emotional affect in favor of a more measured, intellectual response; second, to enforce through the novel a particular idea of reality and the human situation within it.

More innocently, the use of a painterly rhetoric left the novel's lifelike illusion undisturbed. Representational authenticity, from a formal point of view, is useful because when characters and events seem real to readers they become more interesting, thanks to the basic psychological principle of sympathy. To the extent that one understood how they were made to seem real, however, they became less real: art was unmasked as artifice. A vocabulary of painting terms permitted the reviewer to discourse knowingly about the art form without uncovering any of its actual rules of production. The pleasurable experience of novel reading remained undisturbed, and the reviewer, rather than taking pleasure in undermining the novel's achievement, cooperated with it by use of a complicitous discourse. Harper's reviewers said that characters in The House of the Seven Gables were "drawn" in "sharp and vigorous perspective. They stand out from the canvas as living realities," and of Villette that "the plot is simple, almost to bareness. But the personages of the story stand out from this plain canvas with a truly marvelous distinctness, showing the miraculous skill of the writer in the art of dramatic perspective" (May I85 I, April I 853). The reviewer can call attention to skill without having to expose its methods, leaving it miraculous. The technical achievement of making a character stand out from the canvas is not analyzed; indeed it cannot be, since characters in a novel are not figures on a canvas to begin with. Thus, anything we might hypothesize about why figures in a painting who stand out from the canvas seem real is beside the point in the instance of the novel, where canvas is a metaphor. 
Picture language is present in all the journals over the years. The North American in a review of Cooper said that the novelist, in comparison to the dramatist, must "paint at full length," that "novels are pictures of life" (January I 838). The New York Review wound up a review of Balzac by observing that he "has been before us wholly as an artist, and as such, we have endeavored to give some idea of his magic pencil. . . . He who draws from the wide range of human nature, in whatever land he may find the original of his copies, must fill his gallery with many a revolting picture" (April I 839). Peterson's thought Fredrika Bremer "the most exact delineator of character now living; her pictures are finished with all the elaborate nicety of a French painting," and said of Julia Kavanagh that "her minute painting gives a reality to her fictions, which makes them more interesting than those of most other novelists" (October I 843, June I 855). The Democratic Review noted in Lippard's Blanche of Brandywine "two or three portraits very skillfully drawn" (October I 846).

The Cbristian Examiner said that in Mary Barton the characters were "painted by a master's hand," but in Longfellow's Kavanagh "the characters are outlined rather than painted" (March I 849, July I 849). In The Lamplighter, according to a review in Knickerbocker, "every character is a finished portrait. Very artist-like are the pictures drawn of the scenery of our glorious Hudson," and it observed of Chesebro's Getting Along that "the canvas, though full, is not crowded" (May I 854, May I 855). A Tribune reviewer, however, thought the effect of Getting Along "diminished by the attempt to introduce too many conspicuous personages crowding the foreground of the picture, and impairing the proportions essential to the harmony of the whole" (March 30, 1855). The Tribune had also praised Mayo's achievement in The Berber for "the subtle lights and shades of passions, and the distinctive individuality which he is thus enabled to give to the prominent figures of his canvas" (November I I, I 850).

Taking the novel as a static spatial form, this commentary concerns itself with a separation of figures from ground that achieves a vividness and concentration making them seem real. Another important and related metaphor concerns the disposition of light and shade, implying both an idea of artistic skill and 
an idea of the real that the novelist was supposed to represent. When I write "idea of the real" I mean to point to two significant issues: first, the general question of what is taken to be real, and second, a specific cultural concern with the ideal and the real. "Sometimes," a critic in Peterson's wrote of Alice Carey's Married Not Mated, "she paints her pictures too much in shadow. To us, this seems a mistake, artistically, as well as otherwise" (June I 856). The novelist makes an artistic mistake when she paints "too much" in shadow because objects cannot be seen in the dark. She makes a mistake "otherwise" because life is really made up of lights as well as shadows. "The attempt to delineate the lights and shades of character with the truthfulness of nature seems not to have occurred to the writer, as belonging to the task of the novelist," a Tribune review objected on March 2 I, I 854. "We do not know where to look in the whole range of contemporary fictitious literature, for pictures in which the sober and the brilliant tones of Nature blend with more exquisite harmony" than in Adam Bede (Atlantic, October I 859).

The advent of daguerreotypy in the 1840 s strengthened the notion of art as transcription and encouraged the certainty that there was a real world out there sitting for its portrait. "We commend Hawkstone," the Literary World said, "for to the charm of an exciting narrative it adds a kind of daguerreotype of existent religious opinions"; "Dickens daguerreotyped life at the King's Bench prison, in his Pickwick Papers" (March I I, I 848; December 9, I 848). Harper's found in Anna Warner's Dollars and Sense “a transcript from the world about us, whose charm lies in its almost daguerreotype exactness to the original" (September I 852). The Ladies' Repository commended Elizabeth Stuart Phelps's A $P$ eep at Number Five "to those who would have a faithful daguerreotype of a city preacher's trials and enjoyments" (July i 853). Ten Nights in a Bar-Room, according to Godey's, "exhibits the actualities of bar-room life, and the consequences flowing therefrom, with a severe simplicity and adherence to truth that gives to every picture a Daguerrean vividness" (August I 854).

In other instances, artistic deployment of light and shade meant adding something to reality, and this addition might be viewed in different ways. "Though every scene in the story is to the reader, if New England born, as plain as the way to church, and true as the catechism, yet the lights and shadows in this picture of home life 
are so artistically arranged, that we seem walking in Fairyland," Godey's rhapsodized about Kavanagh (July I 849). "It is not enough for an author of fiction to represent society exactly as it is," a long essay on novels in the Christian Examiner stressed (January I 847). "There is a far loftier art. It is, departing from the general truthfulness of nature and life in no single feature, violating no essential probability, so to collocate the figures and dispose the groups, so to distribute light and shade, as to produce a certain whole more richly suggestive than any serviceable copy could be. . . . Real life is not to be departed from, not contradicted; it is to be idealized." Adding to reality by artistic arrangement meant, in these cases, to represent a higher, a truer, truth than that attainable by simple representation of what appears. The ideal, artistically speaking, is translated into the activity of the artist-observer who arranges and intensifies what is perceived: the link between American transcendentalism and normal American Victorianism is evident.

In other instances, describing the specific quality of a book or author, the reviewer considered the artist's additions to or departures from reality in more purely aesthetic terms. In Henry Esmond, the Tribune remarked, "the painting does not, indeed, exhibit such broad contrasts of light and shade-there is no character which starts so prominently from the canvas" as in Vanity Fair or Pendennis, yet "the characters are portrayed with more delicacy and naturalness of finish" (November 30, 1852). Little Dorrit, according to Putnam's, "has the usual bright lights and dark shadows; it is, as usual, a little more grotesque than the life of the day. . . . It has the old extravagance of portraiture" (August 1 857). "In spite of these defects," the Atlantic commented on an Italian novel, "Guerrazzi has succeeded in so intensifying the high lights and deep shadows of passion, pathos, and horror in the story, as to make a very effective picture, of the Caravaggio school" (March i 858).

Reviewers also borrowed the metaphor of outline and filling from painting. In The House of the Seven Gables, "the general outline is well conceived, but the filling up is not of equal excellence" (Christian Examiner, May i 85 I); the journal complained that "the first outlines of character are never filled up" in the Baroness Tautphaeus's Quits (January I 858). Harper's found that in Mary Jane Holmes's Tempest and Sunshine "the outlines of the leading personages are admirably given, demanding only a more 
thorough elaboration to make a superior work" (July i 854). "The actors are drawn in bold outlines, which it does not appear to have been the purpose of the author to fill up in the delicate manner usually deemed necessary for the development of character in fiction," the Atlantic said of Sword and Gown (December I 859). The notion of light and shade, like that of standing out from the canvas, relates to the perceptual categories of foreground and background and to the illusion of three-dimensionality that is associated in turn with the illusion of life; the category of outline and filling is related to the perceptual categories of first and subsequent impressions. Here the activity alluded to is at last temporal; the outline, the first impression, is later modified or completed by filling. Having more opportunities to observe, one gets more and more information, and the figure consequently becomes more and more detailed. (Here is the difference between the sketch and the novel, as well as the painterly genesis of the term "sketch" for the shorter work that never goes beyond its outline.) The temporality invoked here, however, is different from that involved in following out a plot line, since it is cumulative rather than sequential. The figure was really as much there, in the real world, the first time as the tenth; the time involved is the real time it takes the perceiver to assimilate material rather than the time required for the plot to transpire.

A third important painting metaphor is coloration. "We think the style of Deerslayer more polished, and the descriptions of natural scenery traced with greater grace of outline, and freshness, and transparency of coloring, than in any of Mr. Cooper's previous works" (New York Review, October i 84I). "The substance of the book illustrates in vivid colors, the evils of the manufacturing system," the Democratic Review observed of North and South; in her historical novels Agnes Strickland "may heighten the colors of her picture, and that, indeed, is the artist's privilege; but she neither distorts the facts nor falsifies the general accuracy of tradition"; "the colors used" in A. S. Roe's A Long Look Abead, "though heightened here and there, are generally true to our common experience of the world" (February I849, February I 855, April I855).

This metaphor, with its implicit contrast of pale and bright, looks like the contrast between light and shade, but actually refers to a different aspect of painting and of reality. The contrast 
of light and shade is essentially monochromatic and alludes to such associated categories of experience as cheer and gloom, good and evil, joy and sorrow. The contrast implicit in coloration has to do with intensity, richness, and depth. The North American, reviewing Balzac, praised the "extraordinary richness and delicacy in his coloring" (July I 847). The Literary World complained that Lonz Powers by James Weir "reminds us of some life-like engraving, ruined by daubing it over with glaring water colors" (October 5, I 850). The Southern Literary Messenger warned its readers about Southworth's novels: "there could be few greater evils, in our estimation, than the introduction of these warm, highly colored, 'artist' productions . . . into a Virginia family of young girls and boys" (June I $85 \mathrm{I}$ ). Tribune reviewers faulted William Henry Herbert's The Roman Traitor for "excessive warmth of coloring"; found that The Lamplighter "bears the stamp of genuine truthfulness-nothing is overdrawn, or too intensely colored"; thought that in The Old Homestead Ann Stephens's "pictures of scenes in the city, though often drawn in too high colors, are on the whole effective"; and decided that Alice Carey's Married Not Mated was "free from the excess of coloring which vitiated the effect of Hagar" (September 24, I853; May 28, I854; December 6, I 855; May 3, I 856).

Each of the various painterly metaphors utilized by reviewers of novels implied certain proper judgments. It was good art when characters stood out from the canvas and occupied a relatively uncluttered foreground. The picture should contain balanced contrasts of light and shade. It should fill up its outlines. It should be delicately, not excessively colored. As categories for talking about novels, these metaphors' function is substitutive, replacing plot with picture and the engaged, enchained, and excited reader with the contemplative, detached observer. In this way the judgments enjoined an interaction with the novel quite different from that which was inferable from reviewer discussion of the popularity of the novel and the reasons for that popularity. In addition, these putatively aesthetic statements carried with them important normative implications about the real world, not the least of which were that such a world existed independent of observation, could be known through observation, and was representable. Reviewers were frequently more certain about the nature of the real world as pictured in the novel than about the 
art by which the picture was achieved. And truth to nature became a criterion by which superior novels were known.

\section{Nature}

It became commonplace for reviews of the i 850 to see the novel progressing historically toward ever more truthful works of art, and to identify fictional superiority in particular instances with such truthfulness. This, indeed, more than the clever concealment of a moral, was the accepted criterion, but of course truthfulness had an inalienable moral aspect. We recognize familiar nineteenth-century assumptions here: history as progress, the human being as improvable and perhaps perfectible; less familiar, perhaps, is an equation of the improved human being with one who prefers instruction to enjoyment. "What is wanted to constitute a good modern novel," a Putnam's critic expatiated in an essay entitled "Novels: Their Meaning and Mission," "is not a monstrous assemblage of grotesquely illusive pictures of life and nature, interlarded with inconceivable sentiments, unheard-ofadventures, and impossible exploits. Not at all. We demand that they be veritable and veracious segments of the great life-drama, displaying Nature and Man as they are, sentiments as they are felt, and deeds as they are done" (October I 854). The construction of a literary history, and of a supporting canon of major authors, went forward under the aegis of this demand, which imagined novels to have a "mission." In this project the reviewers exacerbated, if they did not create, a division between better and popular novels, simply because popularity has always been based on the capacity of a form to give pleasure to the greatest numbers.

Obliterating or denigrating the pleasure-producing function of the novel and distrusting novels that give great pleasure to great numbers remain characteristics of academic criticism and theory to this day, reminding us of the middle-class Victorian origins of our own habits of literary criticism. "Novelists recognize that Nature is a better romance-maker than the fancy," Harper's commented in a favorable review of Eliot's Scenes of Clerical Life, "and the public is learning that men and women are better than heroes and heroines, not only to live with, but also to read of" (May 
I 858 ). The taste for better novels had to be learned, which meant it had to be taught, and the novel thus became enmeshed in an interaction of instruction rather than entertainment.

The criterion of truthfulness, the emphasis on nature and the real, is much stronger in some journals than in others-indeed it becomes a means of classifying them-and is found much more commonly toward the end of the period, especially in the later fifties. Certain journals were aligning themselves with and to some extent had become advocates of the poetics of a given group of novelists, those whom we now call "realistic" (though the word does not appear in the American reviews of the day) and who still constitute, so far as the English canon is concerned, the major figures for literary study. Harper's and the Atlantic were both important organs in the ultimately successful advocacy of these authors and their works. But I would qualify these comments by acknowledging that it was advocacy - that truthful works and the criterion of truth had by no means achieved the dominance they have now, even as we imagine ourselves to have progressed far beyond Victorian ideology. A debate was in progress; the situation was in flux. I would also note-though the point may be obvious - that even where reviewers agreed that novels should be true to nature, their ideas of that truth were inevitably conventional.

The opposition, if it may be called that, to elevating truthfulness to nature as the means of identifying the superior novel falls into two camps-the idealists who maintained that truth was not enough, and the formalists who insisted that novels were stories, not essays. Both these camps came together in a sense that the novel ministered to desire, whose rules were not necessarily congruent with observed reality. From the point of view of the selfproclaimed idealist, a mere representation of reality-granting it could be attained, which for the most part this contingent didwas insufficient to the needs and demands of that very human nature that the advocates of the novel of the real claimed to be representing.

"In the details of daily life, especially in the ruder forms under which it appears in the wilderness and on the frontiers of civilization, there is much which no skill can make poetical, much which no light of imagination can clothe with the radiance of artistic beauty, much which cannot, by any possible magic of literary 
genius, be raised out of the region of squalid, groveling, repulsive vice and barbarism. This sadly unpoetic side of American life should not, indeed, be kept wholly out of sight in fictitious delineation; but it cannot be brought prominently forward without violating the laws of ideal beauty, under which all the works of imagination must necessarily arrange themselves," the North American commented in a review of the works of Simms (October I 846). "The rule, that fiction must always copy nature, must, obviously, be adopted with some little restriction. To represent man as he is with perfect fidelity would not, in many cases, be desirable. Where the imitation is so exact, the canvas often reflects forms, loathsome, hideous, and repulsive. Would the interest or utility of fiction be increased by such grotesque portraitures?" asked a reviewer in the Southern Literary Messenger (September i 849).

On January I 8 , I $85 \mathrm{I}$, the Literary World wrote that it would not "quarrel" with Thackeray (who for all these reviewers was the ultimate realist) "provided he does not insist upon any exclusive theory in regard to the construction of the novel. He would not tell us that his art must be always imitative, and never creative. He would not surely shut out the ideal from its province. Whether he wills it or not, the world will laugh with Dalgetty and Pickwick, and weep with Little Nell and Jeanie Deans. The experience of this world will never supply us with the humor of one or the pathos of the other. Scott, and Dickens, by the immortal power of genius, have filled that void in the human heart." On June 7 of the same year the journal identified two "schools" of novel writing, one epitomized by Thackeray and the other by Dickens: "Thackeray is essentially an artist of the real school. . . . Dickens, on the other hand, works more in the ideal. It is nonsense to say of his characters generally, intending the observation for praise, that they are life-like. They are nothing of the kind." A slight change in perspective would produce a different sense of the opposition between real and ideal, for Scott and Dickens before i 850 were usually praised for the powerful lifelikeness of their characters, and thereafter as exponents of the ideal.

"We object to the employment of materials like this in a fictitious work, as hostile to the true purposes of art. . . . Granting that their prototypes are to be found in nature, it does not follow 
that they are legitimate subjects for art. A depraved taste may delight in loathsome natural scenes, but no true artist will give them preference over the revelations of beauty with which the Universe is filled" (Tribune, January I, I 853). Godey's (December I 855 ) praised the virtuous sentiments interspersed in the melancholy narrative of The Old Homestead: "were it not for such gems as these to brighten the way, and to solace the hopes of the reader, all such narratives would, however true to life and society, become in a measure intolerable." Grabam's, reviewing The Newcomes, allowed that "Thackeray aims to give the truth, and the whole truth," and that "it is through no fault of his that the world is not what the philanthropist and the sentimentalist desires it to be," but it still preferred writers who "are delineators, not of actual, but of possible life and character," who "not only look into life" but "look through it . . . creating a new world of beings, having its roots and principles in the actual world" (December I 855). According to this description, actuality is not so much the ground as the embellishment of the satisfying fiction, which originates in and is responsive to desire. The Cbristian Examiner took a similar approach to Thackeray: "the key-note is too monotonous, the scene too dreary, the dramatis personae too repulsive for renewed acquaintance. . . . It is not healthful, then, to dwell upon and fraternize with even the truest pictures of life, if they exclusively tend to keep in view its mechanical level, and to strip it of heaven-born illusions" (January i 856). The Home Journal reviewer reported in the novel Berenice "a faithfulness which would be often painful from its startling truthfulness to nature, were it not for that ray of hope, slender though it be, with which even the darkest shades in the picture are illumined" (May 3I, I 856).

The New York Ledger for October 30, I 858, the nation's most popular fiction weekly, attributed the advanced state of contemporary civilization to poets and romance writers, "mainly owing to their prominent principle of keeping the mind dissatisfied with commonplace things, their power of creating images superior in every respect to reality, which we admire and would fain imitate, and the admiration they infuse for what is good and excellent, or sublime and daring. . . . By making us discontented [they] spur us to pursue things beyond our reach, and keep us in progression." "One of the great advantages of fiction, as compared with 
history," observed a reviewer in the Ladies' Repository, is "that it may avoid these hum-drum everyday realities, and realize in imagination the ideal excellences which 'life' so seldom affords. Hence it of ten happens that the greater the number of facts, the less perfect and truthful the story" (May i 859).

Fiction merely truthful to nature, idealists complained, was incommensurate with the human spirit regardless of whether spiritual longings guaranteed the existence of an unseen reality. (Of course they preferred to think it did, but this question was muted in reviews.) The ground of the "formalist" complaint with such fiction was that truthfulness to nature did not make an interesting novel. Because the argument of real versus ideal was more general, and that of nature versus interest more specific to the novel, it is this latter concern that we find more frequently argued in reviews, argued because the proponents of the truthful novel could not afford to allow that the type of novel they advocated was not interesting.

As early as July i 8 I6 the North American, reviewing a work called Rhoda, remarked on the "numerous and constantly increasing class of productions, in which fiction is brought home to daily occurrences and observations" and added that "readers are apt to complain of such that they are monotonous and ordinary." Reviewers for the sober North American constantly advocated the truthful novel but could not deny the significance of the complaint. Even domestic novels, one wrote in April i 825, should not comprise "the dull diary of ordinary occupations, or amusements" but rather "some event, or at least a series of events, of unusual importance, standing out in strong relief from the rest of the biography of [the] principal characters." The American Review commented on a work of Eugene Sue that "so much are we interested in its startling details, that we absolutely lose sight of all the monstrous incongruities and absurdities with which the book is stuffed from beginning to end" (April s 846). "Those fond of the improbable and the unnatural," Godey's grumbled over a Dumas novel, "will, as usual, be gratified to their heart's content" (May I 848). "Actual life, with the element of romance expelled, is dull and depressing," a reviewer for the Literary World admitted on November I 4, I 849. "There is so much namby-pamby fiction about, that when one meets with a novel that rises, like this, to the heights of tragic passion, one can excuse 
many faults of style and even some improbabilities of incident," Peterson's wrote of Southworth's Retribution. "No one equals her in variety of incident, or surpasses her in the interest she imparts to her narrative" (October i 856).

The most acute discussion of the dilemma I have found occurs in a signed essay called "Reading for Amusement" by Caroline Kirkland in Sartain's for March I 850, part of which seems worth quoting at length. "Though we profess to relish most those fictions which are like transcripts of life, we in reality covet a certain exaggeration, and an artful veiling of the more vulgar truths," she wrote. We would not be interested or excited by direct contemplation of "the actual occurrences which the writer of fiction describes," and accordingly it cannot be life transcripts that we desire in fiction.

It is the repose and refreshment of a little illusion that we long for, although this illusion be thrown over the very subjects of all others about which we feel most anxious to discover truth. Yet we persuade ourselves that we accept fiction only as a substitute for truth. This is one of the unavoidable inconsistencies of a condition full of blunders. . . . If the truth be familiar, we despise it, no matter how well presented. "Where's the use of putting all that into a book?" said a plain-spoken western woman, on reading some sketches of the life she saw about her. She did not want suggestions of the homely, though they might suit well enough the child of luxury and wearisome convention. When she selected a book for her own reading, it would be one of the wildest and most exciting romances, perhaps a harrowing ghost-story, or the impossible adventures of some pirate or highwayman. . . Indeed, distance, either of time, place, or circumstance, from the scene of our own knowledge or recollection, seems to be one of the requisites for fascination in fiction, although if this distance be too great it precludes interest by chilling sympathy.

Since the requirement that readers be interested could not be put aside in a context where reading was voluntary, those critics concerned to forward the cause of the truthful novel had to argue, or insist, or claim, or decree that the natural was interesting. In many instances we see this claim advanced with a becoming tentativeness, which acknowledges implicitly that the natural is not naturally interesting but is made so as an artistic achieve- 
ment. "No novelist has at all approached her in the interest with which she invests home-scenes and incidents of every day life, which, in her hand, assume an interest rivalling the more romantic and dignified events of Scott's romances" (Peterson's on Fredrika Bremer, October I 843). "It is a picture of real life, without the least exaggeration, and yet intensely thrilling" (Peterson's, May I 849). These days, the Literary World found, readers demand "a little more nature, not so milk and watery as the nature Mr. Arthur deals us, but in its vigorous state as mixed by Thackeray and Dickens" (August 3I, I 850). Arthur's praised a novel by Mary Andrews Denison as excelling "in the art of throwing around every-day life and every-day scenes a humanitary aspect that elevates the seeming common-place into interest and importance" (July I 854).

His "characters are natural without being commonplace," the American Review said of Thackeray, "and to represent characters in this manner is, we think, the perfection of writing" (May I 85 I). "The dull conventionalities of life become instinct with interest in her hands" (Democratic Review on Jane Austen, March I 855 ). "The incidents and characters are, indeed, striking, but, at the same time, probable, natural, and truthful"; "with all her bold limning, the incidents are natural"; "but, with all this trueness to nature, the work abounds with interest almost to piquancy" (Home Journal, March 24, I 855; March 15, I856; March 29, i 856). "The various characters, and the domestic occurrences introduced, are natural and probable, and will, though quietly introduced, be found sufficiently impressive to sustain the interest, and to reward the curiosity of the reader" (Godey's, June I 857). "Without indulging in extravagance of plot or sentiment, the author throws a vital human interest about his narrative, and produces a deep impression by fidelity to nature and force of illustration" (Harper's on Adam Bede, April i 859).

The more aggressive move was to claim that fidelity to nature became interesting not thanks to authorial skill but simply because nature was interesting in itself. "Her personages," ruminated Knickerbocker, "are, without an exception such as have fallen or might fall within the knowledge of every one; and there is not an incident in the whole progress of the story that almost any one could not match from the stories of his own experience. What is it, then, that makes Allen Prescott a most delightful book 
to read?" It answered, "the very fidelity to nature" (March I 835). Similarly, the Mirror observed that "without the ostentation of profound plot, it is a perfect transcript of some of the most interesting and ludicrous scenes and persons of ordinary life. A strong interest in reality carries you through to the close. No mystery is unfolded, but actions probable in their nature and delightful in their descriptions, become important by their just consequences" (January 9, I 836). Catharine Sedgwick, the North American noted, "writes of minds and hearts, as they muse and beat, not in ancient Rome, nor modern Cumberland, but in the streets of our marts, and the retirement of our villages. So her own mind obtains the excitement, which nothing gives, like the sense of dealing with realities . . . and her readers are wrought to a warm interest by seeing themselves reflected, as in a glass" (October I 837). "Mrs. Haven delineates with ease and skill the characters of everyday life, and invests them with the charms that only fidelity to nature can impart," Godey's editorialized in February I 856.

An Easy Chair in Harper's for June I 859 summed it up in considering Thackeray: his novels "delineate the play of daily life, and of common, but not uninteresting, characters. They deal in no surprises, no scenes, no melodrama and red lights of any kind. And hence they address the highest faculties and the best audience; for their interest springs from their fidelity to nature, and the genial skill with which that fidelity is carried into the minutest details." The summation is important because in referring to the "highest faculties and the best audience" Harper's in effect admits that the appeal of the novel it espouses is limited because nature is by no means universally or inevitably interesting.

"What is a novel?" the Easy Chair asked again in February I 860. "It is a picture of life. Just in the degree that it is a true novel, it is an accurate representation-within such limits of space and time and mutual relation as to make it effective and real in its impression and influences-of the characters and circumstances which surround us all, and with which we are most familiar." The insertion of the normative adjective "true" here is accompanied by an equally telling parenthetical clause admitting that the "accurate representation" is really an artful structure. And we must not overlook the equation of life as it really is with 
characters and circumstances that surround "us all," with which "we" are most familiar. Here the Harper's reviewer betrays another gap in his argument, showing that the reality with which this accurate novel deals is simply conventional. He takes for granted that its "we" speaks for "us all," and that what we-all see around us every day is the real. This is not the same as saying that people are interested in books about people like themselves, a statement that would recognize experiential pluralism and the gap between human perception and the constitution of reality. It is a far more arrogant assertion, advocating, albeit unawares, the truthful novel as an agent of cultural indoctrination, of instruction.

\section{Nature and Convention}

Of course the practice of identifying what one believes to be the state of things, or wishes to claim as the state of things, as "nature" or the "real" is hardly limited to novel reviews in antebellum America. But its prevalence in such reviews shows that the novel had become established by $\mathrm{I} 850$ as a significant site for debates about reality-whether or not novels actually contained views of reality, whether these views were implicit or explicit, reviewers discussed them as though they did and as though these views mattered. Such discussions inevitably recreated the novel as the expository form that reviews took it to be. The novel had become an occasion for a specific kind of cultural discourse, and as such an occasion it lost its formal integrity and coherence, ceased to be "itself," and was dissolved into the stream of culture. From this perspective-the perspective of how it was talked about, what it was used for-the novel, as soon as it became an important cultural phenomenon, was literally translated into a cultural document (which it still remains and indeed now often self-consciously, internally, formally strives to be), although the word used by our commentators was not culture but nature. Because novels were important to so many people, it was important to reviewers that they contain views of nature, and that these views be "right."

There was striking, though perhaps not surprising, accord in these reviews on what were the most important elements of the 
right view of nature. Nature had design, its design was apprehensible by human beings, it centered on and provided a field for human action, and it had an inherent moral dimension; in the long run good predominated over bad and joy over sorrow. In a word: Victorianism, though not the competitive variety that encourages entrepreneurship and individual achievement. Just the reverse, one which concentrates on modest expectations, the presence of powerful external controls and the need for equally powerful internal ones, and the pleasure of duty rather than the pleasure of pleasure. "Our author never separates the tie that unites virtue and happiness, vice and misery, which succeed each other as invariably as thunder follows lightning or as spring comes after winter" (North American on Sedgwick, January I 83 I). In The Scarlet Letter, according to Grabam's, Hawthorne "has made his guilty parties end not as his own fancy or his own benevolent sympathies might dictate, but as the spiritual laws, lying back of all persons, dictated to him. In this respect there is hardly a novel in English literature more purely objective" (May I850).

Ann Stephens's "novels are transcripts of life, not mere ideal pictures. . . . Her men and women are the men and women we meet every day in our streets, with loves, hatred, vanity, generosity, and all other human qualities at war in their bosoms: men and women, who become good or bad, as they strive, or neglect, to work out their progress to a better life, to a higher spiritual condition" (Peterson's, August I 854). As for Peter Gott, the Cape Ann Fisherman, by Joseph Reynolds: "when so many highly wrought and over-colored pictures are sent forth from the press, it is well to have one of these sober, truthful delineations to show us life as it really is-a serious and toilsome march from one duty performed to another yet to be done; and not a fierce battle with fate, from which we come off either victors and triumphant for the rest of our days, or else are left a useless corpse on the field of the struggle" (Godey's, August i 856).

Why is it "well" to have such a novel? And would we be surprised if a novel like this should turn out to be less popular, and its type less common, than the "highly wrought and overcolored pictures" Godey's deplores? If interest, even to excitement, is the principle by which novels enchain their readers and according to which their form must be designed, we can see that 
the reviewers' ideal undermines the novel's formal base. If they are right about nature, then the novel is inherently an unnatural form. To simplify somewhat, the novel, which appears historically as an occasion for self-gratification and pleasure, is being conscripted by the reviewing establishment as an agent of social control. When we remember that the great population of novel readers was thought to consist of the less educated, and to be concentrated among the young and especially the female, we might interpret all these gestures as support for a stable patriarchy.

The class struggle here seems to me less significant than the generational struggle and, above all, the gender struggle. The view of nature set out in these reviews is especially concerned to assert that woman's place is decreed by natural or divine laws and therefore immutable. In March I 846 the American Review castigated George Sand for preaching the "injustice, inequality, and absurdity of the marriage tie, which she admits springs from the dependence of woman upon man, based on a natural law-which law, however, she stigmatizes as unjust - attempting, with shrill outcries, to mar the majestic harmony of nature" (even then feminists were "shrill"). "It is disagreeable to the fancy," the same journal remarked of McIntosh's Charms and Counter-Charms, "to picture a passionate couple, such as these are represented to have been, living in that manner for a long space of time, neither married nor bound in duty to be married. The thing is against nature and reason, and therefore to contemplate it tends to corrupt and unrefine" (October I 848). It complained revealingly about Chesebro's Isa, where an unconventional couple moves to Europe and lives happily ever after without marrying: "would not their 'experiment' have exerted a more healthful influence" on the public mind and "on individual morality, and consequently, security, if the result had shown in its true, its life-light, the consequences of this, as every other violation of that domestic law which cannot be violated with impunity?" (July I 852 ). The American Review was a Whig journal, deeply conservative; the three works it attacked here were written by women.

The Literary World excoriated Brontë's The Tenant of Wildfell Hall for its depiction of an abusive husband: "one of the chief improbabilities of the book consists in the absurdity of supposing any community or family in England would tolerate such a hus- 
band as Mr. Huntingdon among them. In this world men do not maltreat their wives, seduce openly other men's, and beat their brothers-in-law with impunity. The same natural law that decrees the dependence of women guarantees their happiness and safety in the arrangement" (August I2, I 848). It complained about Lady Alice; or, The New Una, in which the heroine spends some time passing as a man, that there is no way "of abolishing the immutable distinction between petticoats and pantaloons"; it approved of Bremer's novels because in them "woman plays the important part nature has assigned her" (July 2 I, I 849; December I, I 849). Grabam's liked Edith Kinnaird because it was "a fiction which the most artistic mind will feel delight in perusing, yet one which the humblest will understand, and from which both may derive improvement. The heroine is neither a saint nor a fool, but a living woman; her sufferings spring from her errors, and are redeemed by her repentance; all is natural, beautiful, refreshing, and noble. . . . Instead of rendering its readers dissatisfied with themselves, and their lot in life, with society, with everything, this novel makes them feel that life is a battle, yet that victory is sure to reward all who combat aright" (May I 848). And a reviewer for the Atlantic praised Out of the Depths despite its sensitive subject (it was the "autobiography" of a prostitute) because the heroine accurately attributed her "fall" to "her vanity and unrestrained passion" (November I 859).

These reviews reveal a social context wherein those who read novels were thought of as discontented, or as easily becoming so; behind the static, perhaps stodgy issue of truth to nature lies the more volatile issue of social unrest, and especially the unrest of the young and the female. The very attraction of the novelreading population to "untrue" novels - that is, novels encouraging discontent-suggested as much and also suggested the advisability of neutralizing the novel's perceived threat. "Recreative books disarm criticism," the Christian Examiner reflected in a long essay on Thackeray in January I 856 . "Yet, if there is one class of works more than another which it is specially desirable to estimate correctly, it is that included under the generic name of popular fiction. If this department of literature does not reflect, it in a degree moulds the age. . . . It is through vivid and fascinating pictures of human life, through the adventures of some hero or the sentiment of some heroine $[s i c]$, that we usually image our 
own career, or, at least, first shape our ideal of what it should be. . . . It is on account of this enduring and personal agency of the gif ted novelist, that it becomes requisite to examine his claims by a more comprehensive test than the direct moral of his story, or the degree of cleverness it manifests." The essay continued: "there is of ten a perverse mood in genius that leads to the choice of subjects which it only irritates or revolts the mind to contemplate, or to such a treatment of more legitimate themes as distorts and renders grotesque the facts of nature"; and it concluded, despite its own counterexamples, that art "is essentially conservative, and aims to keep alive sentiments which the world too of ten blasts." As the descriptive gives way to the normative here, one wonders whether the real perversity was not in the reviewer, determined to ignore the inextricable psychological linkage of excitement and interest with dissatisfaction. If art were essentially conservative, it would not be necessary to insist that it ought to be.

Apart from the question whether novelists were or were not radical in the particularities of their social, sexual, or personal world views-quite apart from the question whether they wrote to situate those views in an authenticating fiction-lies the possibility that the form of the novel assumes discontent as the psychological ground from which it springs. The essence of plot, after all, is that something is wrong; there is a disturbance that needs correcting. Because women and youth mostly read novels, it was thought, their discontents in particular would be ministered to and hence exacerbated. The conviction of many contemporary students of popular culture that popular forms sedate discontent was not held by this earlier group of critics. If, as many feminist critics have argued, the "better novel" appears regularly to be instinct with misogyny, this may not be an accident. Novels putting women in their place may well have been selected by reviewers as better than-more true to nature thannovels that legitimated their discontents. 